\title{
Cooperative versus Conventional (Joint- Stock) Banking In Europe: Comparative Resistance And Resilience During The Recent Financial Crisis
}

Mireille Jaeger, University of Lorraine, France

Yasmina Lemzeri, University of Lorraine, France

Jean-Noel Ory, University of Lorraine, France

\begin{abstract}
During the banking crisis of the 1990s, French cooperative banks emerged as more resistant and efficient than jointstock banks, which enabled them to improve their market share and increase their reserve capital. This subsequently became the keystone of the external restructuring that led to the transformation of cooperative banks into large universal banking groups. At the time, their competitive advantage relied mainly on a different approach to risk-taking, which was associated with their cooperative legal form and their specific governance model.

However, the same features have clearly not prevailed during the financial phase of the most recent crisis. Whereas governance models in the banking sector have been deeply questioned, the original cooperative model has evolved differently within European countries, with a high level of hybridization in some and a very diffuse cooperat ive network in others. Some European cooperative groups have been damaged by the crisis, mainly because of the corporate and investment banking that formed part of their activity.

Yet the recent crisis has revealed the importance of a resistant and resilient worldwide banking system and the diversity of legal forms and organizations could contribute to achieving this goal. In this paper, we assess the resistance and resilience of major joint-stock banks during the crisis and compare them to cooperative banks in different European countries and Canada. We conduct our analysis at an aggregated/consolidated level for these two categories ofbanks. Using different indicators (e.g., z-score, loans to the economy, return on equity) as dependent variables, we verify whether the cooperative form is synonymous with greater resistance or resilience, and whether the results may be explained by different organizational schemes in cooperative banking.
\end{abstract}

Keywords: Cooperative Banking; Financial Crisis; Resistance-Resilience

\section{INTRODUCTION}

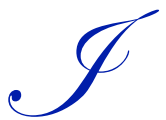
n France, during the 1990s, cooperative banks were able to compete efficiently with publicly listed jointstock banks and they were revealed as more resistant and better capitalized. At the time, both their global market share (credit and deposit) and the perimeter of their activity increased. External restructuring led these banks to buy or to take a majority stake in the capital of a considerable number of joint-stock banks that were experiencing financial difficulties (Gurtner, Jaeger \& Ory, 2002; Ory, Gurtner \& Jaeger, 2006). The main competitive advantage of the cooperative banks was their better risk management, which entailed a lower cost of credit risk. As the required return on equity was lower for their members than for the shareholders of conventionalbanks, they were also able to keep a solid intermediation margin, or to impose lower interest rates on their loans. In this way, the cooperative model (with its specific governance and networked organization) could be vie wed as a strength rather than a weakness (Gurtner, Jaeger \& Ory, 2006). 
Over the last two decades, the situation has changed, particularly in France. The cooperative model has become increasingly hybridized and the formation of large cooperative banking groups can be viewed as a process of standardization towards the conventionaland dominant model in the banking sector (Ory, de Serres \& Jaeger, 2013), involving as it does a large range of activities and products provided by joint-stock subsidiaries, with a listed vehicle such as the holding, or even the apex of the group. Moreover, it seems that some of these cooperative groups have not been protected against the recent financial crisis.

Yet, as the worldwide financial system works to reinforce its strength and stability, cooperative banking could logically contribute to achieving this goal (Groeneweld, 2011). The main objective of this paper is to compare the resistance and the resilience of cooperative banking to that of conventional(joint-stock) banking, during the financial phase of the recent cris is (2007-10).

We define resistance as the ability of the different banking groups to withstand the crisis, and resilience as their ability to overcome the difficulties and recover after the crisis.

As the features of cooperative banking are not unique, and may be quite different (Ayadi et al., 2010), the scope of this paper is quite broad, taking into account not only the French situation, but also that of other countries (nine European countries and Canada). More precisely, we investigate not the banks themselves, but cooperative banking groups versus joint-stock groups. Indeed, the organization and structure of cooperative banking may be quite different between these countries. In some, cooperative banks are now part of large universal banking groups (with a more or less integrated cooperative network), whereas in others, a large number of local cooperative banks (or credit unions) coexist, in a very deconcentrated model(Ory \& Lemzeri, 2012). However, in all these cases, the underlying hypothesis is that the specific goals and governance of the cooperative model could help identify more effective resis tance to the financial crisis.

In the first part of the paper, we draw on the literature to show why the cooperative banking model could be expected to be more resistant to a financial crisis (section 2). Then, we explain the methodology and the indicators that have been observed to assess the resistance and the resilience of both types of banking group (sect ion 3 ). In section 4 we present our results and main conclusions.

\section{WHY ARE COOPERATIVE BANKS EXPECTED TO BE MORE RESISTANT TO A FINANCIAL CRISIS?}

The specificities of the cooperative governance model do not encourage risk-taking, and are not an incentive to achieve short-term performance (section 2.1): in this sense, cooperative banking could help to achieve greater stability of the financial system. However, as the hybridization of the cooperative model may also hinder this stabilizing effect, it is necess ary to dis tinguish several types of cooperative banking group (section 2.2).

\subsection{The Stabilizing Effect of Cooperative Banking: A Theoretical Analysis}

Compared with conventional banks, cooperative banks have special features: their capital (in the form of shares) is owned by their members, who are also customers of the bank. Compared to stocks, these member shares confer relatively limited rights. Voting is limited to "one member, one vote," remuneration of member shares is capped, and reserves cannot be divided. As a result, the managing directors of cooperative banks have a high degree of autonomy, compared to the principal-agent theory that characterizes joint-stock companies. Moreover, the organizational architecture and double-sided governance model (representatives elected by the members, and besides, managing directors) are likely to highlight objectives that are not simply looking for short-term performance and maximizing the value created for the shareholders. 


\subsubsection{Cooperative Banks: Management Practices Favor Stability; Corporate Objectives Prevent Excessive Risk - Taking}

Unlike joint-stock banks, which have to focus on the return on equity required by their stockholders, cooperative banks also have to answer the needs and requirements of their members as customers, not just equity owners. Therefore, they are supposed to provide attractive savings products, or loans with lower rates than tho se required by conventional banks. As members are simultaneously customers and decision-takers who own the capital (at least at local level), cooperative banks have an incentive to undertake less profitable but less risky activities than those undertaken by joint-stock banks (Gurtner, Jaeger \& Ory, 2006). Moreover, reserves cannot be divided and cannot be claimed by shareholders. This feature favors stability, because it serves an intergenerational purpose and enables equity conservation buffers to be established easily, lowering the risk of bankruptcy (Amess, 2002). An after-effect is to secure deposits (Rasmusen, 1988).

\subsubsection{Lower Dependence on Financial Markets and Short-Term Performance}

Unlike joint-stock banks, cooperative banks do not issue listed or publicly traded member shares. The return of equity $(R O E)$ requirement is therefore weaker, allowing them to undertake less risky projects; consequently, the volatility of results is also lower. Also, cooperative banks are not threatened by takeover bids, which might prevent them from focusing only on short-term performance.

Whatever legal form a bank takes (cooperative or joint-stock), profitability is necessary to ensure its economic survival and development. While some authors (Hansmann \& Kraakman, 2001) argue that cooperative banks are doomed to disappearbecause of their lack of profitability - the result of excessive operational costs (Akella \& Greenbaum, 1988) or conflicting objectives) - others (Allen \& Gale, 2004) emphasize that the main goal of a cooperative's members is to maintain its activity, which explains why a larger portion of profit is allocated to reserves rather than distributed. They consider that the long-term value of a cooperative firm is likely to be higher, compared to the short-term requirement for market profitability (in a joint-stock company).

\subsubsection{Executive Compensation is Less Tied to Financial Performance}

Unless they are embedded in large hybrid groups with a listed vehicle, cooperative banks have not implemented compensation schemes (such as stock-options or allotments of bonus shares to shareholders) that are linked to the market value of the firm. In joint-stock firms, these compensation schemes were created to align managers' incentives with those of shareholders, and are more likely to induce excessive risk-taking behavior (Beltratti \& Stulz, 2011).

\subsubsection{Lower Information Asymmetry and Better Customer Homogeneity}

Thanks to better customer homogeneity (Lamm-Tenant \& Starks, 1993) and a strong loan relationship, individual credit risk in the creditor-debtor relationship can be reduced, in comparison to conventional banks (Hansmann, 1985; Hart \& Moore, 1990; Berger \& Mester, 1997). The twin identity of members (who are simultaneously customers and equity owners) may allow cooperative banks to benefit from a comparative advantage in reducing the asymmetry of information (Amess, 2002).

\subsubsection{Greater Geographic Coverage and Better Financial Support to the Local Economy}

Cooperative banks are used to lending to SMEs located in their geographic area. Although SMEs are often considered risky counterparts, cooperative banks benefit from a learning by doing advantage, and thus are experienced in managing this credit risk. They also benefit from greater diversification in their loan portfolios (Amess, 2002). Moreover, as the administrators (also members) of a cooperative bank are often entrepreneurs themselves, they know how difficult it is for SMEs to find funding. Consequently, cooperative banks can be expected not to reduce (as much) access to credit during a period of financial or economic crisis. 
Overall, these governance features are relatively unfavorable to achieving maximum performance when financial markets perform well, but do favor greater stability in periods of financial crisis. In those conditions, cooperative banks should:

- be more resistant, as they are better capitalized, with lower risk-exposure;

- continue to support the financing of the economy to a greater extent than, joint-stock banks;

- exhibit relatively stable financial performance, even if their pre-crisis performance was lower than that of conventional banks.

We will verify these hypotheses in section 3 . However, we have to take into account the recent hybridization of the cooperative model, which leads to different governance features and organizations within the cooperative banking sector.

\subsection{Hybridization and Diversity in Cooperative Banking}

The comparison between cooperative and conventional (joint-stock) banks is not easy to achieve. Although widespread and powerful within the banking sector, the cooperative model is not actually unique. Its structure and organization differ greatly between countries, especially in Europe (Ayadi et al., 2010). In some countries, cooperative banking has changed profoundly since the mid-1990s, and the original cooperative model has become increasingly hybrid.

Nowadays, most cooperative banks are part of cooperative banking groups, with differing degrees of int egration, different scopes of activity, and different organizational schemes or structures (Desrochers \& Fischer, 2005; Ory \& Lemzeri, 2012). In practice, the term "cooperative group" refers to cases and situations that are not homogeneous, as the characteristics of these groups may differ dramatically. In view of this, we have identified three types of cooperative banking group, according to their degree of hybridization: high-hybrid, low-hybrid, and mid-hybrid.

\subsubsection{High-Hybrid Cooperative Banks}

Some cooperative banking groups are characterized by a high degree of hybridization: in these groups, all the banks are organized as a network (at local/national or local/regional/national level), and are more or less integrated. However, along with the cooperative network, a large number of joint-stock subsidiaries (in $C I B$, insurance, forex, real estate, etc.) are embedded in the group, and are owned either by a holding company, or directly by the group's national body (which we term the network central institution or NCI). Moreover, although the NCI is still majority owned by the cooperative network, it no longer has any cooperative legal form (and is actually a joint-stock company). Most of the time, it has a very important driving role, in terms of centralization processes (data processing and reporting), risk management, or defining strategic choices for the whole group (Ory, De Serres \& Jaeger, 2013). In practice, the NCI is also the apex of the group. In these cooperative banking groups, the scope of activity has become very wide, and there is no longer any noticeable difference in the range of financial products available to their customers than those available to the customers of joint-stock banking groups. Thus, the perimeter of activity of the group is consolidated and consequently published results and performance indicators are expres sed as consolidated data. Another significant feature is the existence of a floating listed vehicle (often the holding-company, and sometimes the NCI itself). As a consequence, the cooperative banks and their specific corporate objectives and values coexist with a shareholder value logic and a new kind of stakeholder, i.e., the stockholders (Ory, Gurtner \& Jaeger, 2006).

We assume that high-hybrid groups are most likely to be found in France (Crédit Agricole, Banque Populaire, and Caisse d'Epargne), Austria (Raiffeisen), and Finland (OP-Pohjola). Although they are more independent and less organized as a network, we have included the Italian cooperative banks of the Instituto delle Banche Popolari Italiane in this category, because some or them are listed on the financial market as share-issuers, and exhibit a high degree of hybridization in terms of the scope of their activity. 


\subsubsection{Low-Hybrid Cooperative Banks}

With low-hybrid banks, the meaning of "cooperative group" is much weaker. Indeed, the perimeter of the whole group is almost identical to that of cooperative banks dedicated to very simple financial products (in particular loans to individuals, farmers, or SMEs). The cooperative network is very decentralized, with a lot of local banks, generally affiliated to an NCI. However, in practice, the NCI can hardly be considered the apex of the group as it has no strategic or operational role; its general function is to provide logistical support or institutional representation. This group has no joint-stock subsidiaries owned by an NCI or holding-company. Consequently, the range of financial products and services provided to the customers/members is smaller than that of other types of cooperative group. Group activities are not consolidated, and neither are the published financial data. We cannot find a listed vehicle in any such group.

This low-hybrid type of cooperative group is probably most similar to the orig inal cooperative model. The category contains Spanish and Portuguese cooperative banks, Austrian Volksbanken, Italian cooperative banks (Banche di Credito Cooperativo), and UK building societies.

\subsubsection{Mid-Hybrid Cooperative Banks}

There is another intermediary category, with mixed features, which we call mid-hybrid cooperatives. Although there may be a large number of local cooperative banks within the group, the cooperative network is more integrated than the low-hybrid group. The range of financial products available to customers/members is also greater, with some jointstock subsidiaries owned by a holding company or the national body. In some of these groups, the scope of activity may be quite broad, for example, on financial markets, corporate and investment banking, or overseas. As a consequence, the perimeter of the group is expressed with consolidated data and the NCI plays a strategic role for the group. However, there is no listed vehicle, and the short-term requirement on equity is probably lower than that of the high-hybrid group.

This category includes the German DZ-Volksbanken and the Dutch Rabobank group, as well as the French Crédit Mutuel group, although the latter does have a listed vehicle (CIC, which is a plc banking group, owned by Crédit Mutuel's most important caisse régionale). However, part floated on the market is small (less than $2 \%$ ) and the organization and structure of the Crédit Mutuel are still much more decentralized than the other French cooperative groups (there is no single apex). We also took into account the French Crédit Cooperatifgroup, despite the fact that legally it has been part of the Groupe Banque Populaire since 2003. However, the Crédit Cooperatifis still a group in itself, ${ }^{1}$ with a specific brand and name, a consolidated but specific perimeter of activity, and a high degree of independence. Its activity, governance, and practices have specific features (for example, today it is the only French cooperative group that allows rebates levied from its net income to be distributed to its members). We also include the Canadian Mouvement Desjardin, Coast Capital and Vancity Credit Unions in this category, in consideration of their size and activity, the existence of a real network, and the publication of consolidated data and results. Their overseas activity is insignificant.

We used these three categories, derived from the different hybridization features of cooperative banks, to build three different dummies (see section 3.1) in the following model, the aim of which is to check whether the degree of hybridization in cooperative banking could be correlated with resistance/resilience to the financial crisis.

\section{METHODOLOGY}

\subsection{The Methodological Approach}

Our aim was first, to as sess whether, globally, cooperative groups behaved differently than joint-stockbanking groups, before and during the financial crisis. Can we discern a different level of resistance or resilience to the crisis? Second, we wanted to establish whether these differences in resistance/resilience could be explained by different degrees of hybridization within the different cooperative groups.

${ }^{1}$ For more details, please go to http//www.credit-cooperatif.coop

Copyright by author(s); CC-B Y 
To achieve this, we began by analyzing some descriptive statistics for each of the observed res istance/resilience indicators, computed as averages for each type of banking group (see Appendix 2). However, we also had to control for the different countries in which the cooperative and joint-stock groups are located, as these differences may also depend on specific country characteristics (institutional or regulatory environment, possible differences in accounting rules, ${ }^{2}$ the country's macroeconomic situation, and so on). In practice, microeconomic studies, whose aim is to analyze the factors of performance in the banking sector, often introduce country dummies in their model (see, for example, Beltratti \& Stultz, 2011; Caprio, Laeven \& Levine, 2007).

Consequently, in order to check for different behaviors in terms of resistance (resilience) to the crisis, we estimated a very simple model, with cross-section data:

$$
\text { Indicator of Resistance }=c+\alpha \operatorname{Coop}+\Sigma \beta_{p} D_{p}+\varepsilon
$$

where Coop is a dummy variable, whose value is 1 when the banking group is "cooperative" (omitted variable: jointstock) and $D_{p}$ are country-dummies (omitted variable: France).

For each of the estimated indicators, the $\alpha$ parameter allows us to capture the average difference in resistance / resilience for cooperative banking groups (versus joint-stock banking groups), the country effect being controlled.

We then ran a second version of this model, splitting the "cooperative groups" sample into three categories, acc ording to the different features in governance and hybridization described in section 2.2 (see also Appendix 1):

$$
\text { Indicator of Resistance (resilience }=c+\alpha_{1} \text { LHcoop }+\alpha_{2} \text { MHcoop }+\alpha_{3} \text { HHcoop }+\Sigma \beta_{p} D_{p}+\varepsilon
$$

where LHcoop is a dummy variable, whose value is 1 when a cooperative group is classified as a low-hybrid cooperative group; MHсоop is a dummy variable, whose value is 1 for a mid-hybrid; and HHcoop is a dummy variable, whose value is 1 for a high-hybrid.

Thus, the $\alpha_{1}, \alpha_{2}, \alpha_{3}$ coefficients allow us to assess a possible difference in resistance (resilience) between cooperative groups during the crisis, according to the degree of hybridization of their governance model and organization (compared to conventional joint-stock banking groups).

\subsubsection{Sample and Data}

Data were collected or computed for joint-stock and cooperative banking groups for France, the Netherlands, the United Kingdom, Germany, Portugal, Spain, Italy, Austria, and Canada, using the Bankscope database (Bureau van Dijk).

We focused on cooperative banking groups, rather than individual cooperative banks (Chiaramonte et al., 2013) embedded in one group. This had two consequences on how resistance/resilience indicators and explanatory variables were constructed and taken into account.

The first is that we used consolidated data (i.e., including the activity of the cooperative banks and the activities of other entities belonging to a cooperative group), whenever they were available on Bankscope. This was generally the case when joint-stock subsidiaries were directly owned by the apex or by a holding subsidiary in the group. More precisely, this was the case for all the joint-stock groups, the French cooperative groups (Crédit Agricole, BPCE, Crédit Mutuel), the Dutch Rabobank, Finnish OP-Pohjola, and Canadian Vancity, Coast Capital and Desjardin groups.

\footnotetext{
${ }^{2}$ In our analy sis, all financial data and ratios are ex pressed according to IFRS accounting rules, for the whole period, except for Canada (joint-stock and cooperative groups), where they are expressed in local GAAPS.
} 
The second is that the term "cooperative group" has a very weak meaning for low-hybrid cooperative banks. Therefore, no consolidated data are published. To deal with, the activity of the different cooperative banks has been aggregated, in order to build aggregated indicators and ratios. This is the case for the Spanish, Portuguese, and Italian cooperative banks (Credito Cooperativo), and for the British building societies.

In two specific cases, the Austrian Raiffeisen group and the German DZ-Volksbanken group, the results of the jointstock subsidiaries they own are consolidated and available, but the activity of the cooperative banks is not included in the consolidated results of DZ or Raiffeisen, even though, in practice, they are embedded in those groups. Consequently, we built data and indicators that could include not only the consolidated perimete rs of activity of jointstock subsidiaries, but also those of the cooperative banks (via aggregated data).

Although this methodological choice might be disputed, it was the only way that allowed the bias (from a different consolidation statement of the data available on cooperative banking) to be reduced, and international comparis ons to be made.

A representative sample of 29 joint-stock banking groups was built, located in the same countries as the cooperative groups, and selected according to a maximum size criterion (total of assets) and the fact that all were extant over the whole period studied (2005-11).

Finally, data are available for a sample of 47 banking groups (all of them in activity throughout the whole observation period), 18 of which were cooperative groups.

\subsubsection{Observation Period}

Available data cover the period 2005-11 (annual periodicity, end of the year).

We depict the situation of the two types of banking group prior to the financial cris is that occurred in 2007 , and observe the sub-period 2007-8 to assess resistance to the financial phase of the crisis.

As banking groups (especially the joint-stock listed banks) generally exhibited better financial results after 2008, we considered the 2009-10 sub-period as a phase of resilience in response to the financial crisis. Although the same data were available for 2011, we decided to consider this year separately rather than include it in the resistance or resilience sub-periods. Indeed, by 2011, most European banks were facing a second economic phase of the crisis, which had a feedback effect on banks' balance sheets, especially those of banks experiencing the European sovereign debt crisis component. We maintain that this economic phase of the crisis had different roots than the financial phase, and the situation has to be dealt with differently.

\subsection{Definition and Specification of Resistance/Resilience Indicators}

We consider a banking group to be resistant to the crisis if it can simultaneously limit its own risk of failure, maintain its activity (especially its ability to provide financing to the economy), and preserve a sufficient financial profitability on its equity capital.

Conversely, we define resilience as the ability of a banking group to recover after a phase of crisis and quickly reach a level of activity close to its pre-crisis level.

\subsubsection{How to Measure Resistance/Resilience to the Crisis?}

To assess resistance/resilience to crises, we focused on three different indicators: the first is designed to assess the financial strength and distance to default of the banking groups; the second allows us to as sess the dynamis $m$ of the banking activity, especially for financing the economy; the third is a classical measure of financial performance. 
To measure the financial strength and distance to default of a banking group, we have considered the $z$-score and its rate of change (expressed in \%). The greater the indicator, the better it is for the banking group. There are several coexisting definitions of the z-score, apart from Altman's (1968). We adopted a definition similar to that used by Laeven and Levine (2008), which can be found in other studies published by the CEPS (Ayadi et al., 2010), the IMF (Hesse \& Cihak, 2007), or in Chiaramonte et al. (2013). This definition seems more suited to the goal of our analysis, as it also includes a volatility (risk) component.

The indicator is built as

$$
z \text {-score }=(K+\mu) / \sigma \text {, }
$$

where $K$ is the ratio capital equity/total assets, $\mu$ is the return of the assets $(R o A)$, and $\sigma$ is the standard deviation of the RoA, over the period 2004-11. Consequently, this indicator takes into account not only the capitalization of a bank, but also the profitability and the risk ${ }^{3}$ of its assets. More precisely, the $z$-score corresponds to the number of standard deviations below its expected value that a bank's ROA has to drop before equity is depleted (Laeven \& Levine, 2008). We observed this ratio in level and variation. For the latter, we decided to take into account the rate of change rather than the difference in z-score: consequently, for the same loss of z-score points between two dates, the lower the $z$ score at the beginning, the more the bank will be penalized, because of the proximity of bankruptcy.

To assess how the different banking groups have contributed to the financing of the economy, we observed the ratio loans on assets, and the variation (in \%) of the outstanding loans to the economy, excluding interbank lending. Although the use of indicators that focus on loans may be debatable, on the grounds that they do not reflect the entire activity of the banking groups, they are significant because of their economic role or their social utility, which has been questioned during the crisis, and which has justified the financial support for the banking sector organized by several countries.

The financial performance and ability of a banking group to maintain its profitability is measured by the return on equity $(R o E)$. As the return on assets is already included in the z-score indicator, it was not observed as an independent profitability measure in our analysis.

\subsubsection{Specification of resistance/resilience indicators}

According to the indicators, the variables were introduced in the estimated models, in either level or variation (rate of change, in \%). More precisely, the dependent variables were successively estimated as follows:

For financial strength (and distance to default):

- $\quad z$-score 2006: level of the $z$-score in December 2006, to depict the situation prior to the financial crisis.

- $\quad \Delta z$-score06_08 $=\Delta$ zscore06-08/zscore06: the rate of change $(\%)$ of the $z$-score between December 2006 and December 2008 (sub-period of resistance).

- $\Delta$ z-score08_10 $=\Delta$ zscore08-10/zscore08: the rate of change $(\%)$ of the $z$-score between December 2008 and December 2010 (sub-period of resilience).

\footnotetext{
${ }^{3}$ In this study, the standard deviation of the RoA is calculated over the whole period surrounding the core of the crisis, and does not change over the period of study, for either cooperative or joint-stock banks. Besides the fact that it would not be possible to divide the period into different subperiods (because of insufficient data), the st andard deviation is also considered as a variable characterizing the long-term risk of the assets, which justifies this choice of methodology.
} 
For the loan activity of the different banking groups:

- loans on assets (2006,2008, 2010): net outstanding loans (excluding interbank lending) on total on as sets (end of year).

- $\quad \Delta_{-}$loans06_08 $=\Delta$ loans06-08 / loans06: the variation of the net outstanding loans, expressed in rate of change (\%), between December 2006 and December 2008 (resistance sub-period).

- $\quad \Delta \_l o a n s 08 \_10=\Delta$ loans 08-10 / loans08: the variation of the net outstanding loans, expressed in rate of change (\%), between December 2008 and December 2010 (resilience sub-period).

For the financial performance of the banking groups:

- RoEa-0506: the financial performance of a banking group before the crisis, expressed as the average annualized return on equity over the sub-period 2005-6. ${ }^{4}$

- RoEa-0708: the average return on equity, during the core period of the crisis (2007-8). This indicator is used to as sess the resistance of a banking group.

- RoEa-0910: the average return on equity, during recovery from the crisis (2009-10). This indicator is intended to capture the resilience of a banking group.

- RoEa-0711: the average return on equity from the beginning of the crisis to the end of the observation period.

\section{RESULTS}

\subsection{Before the Crisis: a Better Position for the Cooperative Groups}

\subsubsection{The Strength and Financial Stability of Cooperative Banks}

Our observations of the data before the crisis (2006) leads us to the conclusion that, on average, cooperative groups were better capitalized and stronger that joint-stock groups, as their z-score indicator was much higher (with a difference of 19 points - see Appendix 2, Table 2). However, the situation is apparently not uniform across the three categories of cooperative groups. The comparative advantage is much higher for the mid-hybrid groups, whereas the high-hybrid groups exhibit a $z$-score that is not very different from that of joint-stock groups (3 points difference).

However, as we suggested in section 3.1, the situation may also differ across countries. So, in the next step of the analysis, we aimed to confirm or deny this feature, with an estimated z-score controlled by the countries, first for all the cooperative groups (see Appendix 3, Equation 1, Model 1):

$$
\text { zscore } 2006=c+\alpha \operatorname{coop}+\Sigma \beta_{p} D_{i p}+\varepsilon_{i}
$$

and then by splitting the different cooperative groups according to their degree of hybridization (cf. Appendix 3, Equation 1, Model 2):

$$
\text { zscore2006 }=c+\alpha_{1} \text { LHcoop }+\alpha_{2} \text { MHcoop }+\alpha_{3} H \text { Hcoop } 3+\Sigma \beta_{p} D_{i p}+\varepsilon_{i}
$$

The estimated model confirms the previous result: on average (Model 1), the $\alpha$ coefficient is positive and significant, which denotes a higher $z$-score for cooperative banking groups than for joint-stock banks (12 points more). This conclusion is in line with Fonteyne (2007) and Hesse and Cihak (2007), who state that, thanks to better capitalization and less volatile results, cooperative banking may make a positive contribution to global financial stability.

However, if we focus on the more detailed Model 2, depending on the degree of hybridization, only the $\alpha_{1}$ parameter turns out to be significant and positive, which denotes the comparative strength of mid-hybrid cooperative groups.

\footnotetext{
${ }^{4}$ As opposed to the z-score, in 2006 return on equity $(R o E)$ in the banking sector reached a quite unusual level. To take account of this feature, we decided to include the year 2005 in the calculation of financial performance prior to the crisis. 
It should be noticed that, whatever version of the model is referenced, the estimated coefficient of the country -dummy is both positive and significant for the Netherlands, suggesting the comparative strengh of the country's banking system, whatever the status of its banks.

\subsubsection{Financial Performance}

If we observe financial performance before the cris is (average annualized $R o E$ over 2005-6, Appendix 2), the indicator seems to be in line with the theoretical assumption: on average, it is lower for cooperative banking groups than for joint-stock banks (4.3 points below). More precisely, it is obvious that the lower the degree of hybridization of cooperative banks, the lower their financial performance. Conversely, one of the most hybrid banks does not seem to differ significantly from that the joint-stock banks (2.2 points below), confirming the importance of the profitability objective.

Controlling with a possible country effect, ${ }^{5}$ the estimated model applied to the cooperative groups as a whole, as opposed to the joint-stock groups, confirms that the Coop coefficient is both significant and negative, denoting weaker financial performance for the cooperative (4 points below) before the cris is (see Appendix 4, Model 1, Equation 4). It also confirms that the return on equity exhibited by the most hybrid cooperative groups is not significantly different from that of joint-stock groups, as shown by the HHcoop acoefficient (see Appendix 4, Equation 4, Model 2).

This last conclusion is in line with the assumption that a standardization process towards shareholder value is now spreading within some cooperative groups (Ory, De Serres \& Jaeger, 2013).

\subsubsection{Loan Activity}

If we observe the situation prior to the crisis, in 2005 or 2006, on average, and in line with the theoretical assumption, cooperative banking activity is more credit-oriented than joint-stock banking (with a net outstanding loans on assets ratio 14 points above, as shown in Appendix 2). This fact is confirmed by the estimated model, controlling by the country-dummies.However, the difference on this ratio is much weaker between the joint-stock and high-hybrid cooperative banking groups ( 5 points, at a $10 \%$ threshold ), than between the joint-stock and low- or mid-hybrid cooperative groups (16 and 20 points, clearly significant at a 5\% or 1\% threshold; see Appendix 6), thus confirming the hybridization proces s described earlier.

\subsection{Resistance to Crisis}

In the next step of the analysis, we aim to assess resistance to the financial crisis, by observing the evolution of the three indicators listed above over the period 2007-8, the core of the crisis.

\subsubsection{The Strength of the Banking System and its Contribution to Financial Stability}

At first, it is noticeable that all the banking groups experienced a decline in their $z$-score between 2006 and 2008 (see Appendix 2). However, the average drop of the z-score is much more limited for cooperative than for conventional banking groups. The estimated model, run on the variation of the z-score (in \%) and controlled by the countrydummies, confirms this: the Coop coefficient is significant and positive (see Appendix 3, Model 1, Equation 2), denoting the lower decline on this ratio. This first result suggests that cooperative groups have contributed to greater stability of the financial system.

However, there is weaker evidence when the degree of hybridization is taken into account, or because of contrasting situations between different countries. The MHCoop coefficient is the only significant one (at a 10\% threshold; see Appendix 3, Model 2, Equation 2), which leads us to conclude that only this type of cooperative group was more resistant than the joint-stock groups. Some of the country-dummies turned out to be positive and significant (Canada,

\footnotetext{
${ }^{5}$ None of the country-dummies turned out to be significant, whatever version of the estimated model ( 1 or 2 ) used.
} 
Spain, the Netherlands, Italy, Portugal), which suggests that the strength of their banking systems was less affected at the core of the crisis than the French system.

\subsubsection{Financial Performance}

If we compare the financial performance of the joint-stock banking groups before and during the crisis (2007-8), we can see that the situation changed dramatically, with a 9-point drop in the average annualized return on equity (see Appendix 2). If the decline experienced by cooperative groups was only half as bad, the situation was nevertheless very contrasted, according to the groups' degree of hybridization: the less hybrid they were, the less the decline. If we focus on the most hybrid groups, we see that they behave exactly like the joint-stock groups (a drop of 9 points), which illustrates again the phenomenon of convergence towards conventionalbanking (Ory, De Serres \& Jaeger, 2013).

However, if we control for a possible country-effect in the estimated model, none of the coefficients turns out to be significant, which lowers the pertinence of the previous conclusion (See Appendix 4, Equation 5, Model 1 or 2). Moreover, the significance of several country-dummies points to the comparatively weaker resistance of the French banking system (whatever the status of the banks), which is largely explained by the "Dexia effect."6

\subsubsection{Contribution to Financing the Economy}

The descriptive statistics (see Appendix 2) show that, surprisingly, not only did the net outstanding banking loans to the economy not decline at the height of the crisis (2006-8), but they even kept on growing. This might be explained by the financial support from the different governments and the monetary policies of the central banks. This finding holds true, regardless of the type of banking group. Moreover, when we consider the rate of change, it seems that globally, joint-stock banking groups behave better than cooperative groups.

However, the ratio loans to assets has not evolved much and clearly still favors cooperative groups (with a noticeable drop of 2 or 3 points between 2006 and 2008 for the high-hybrid and mid-hybrid groups).

Controlling for a country-effect, we first ran a model estimating the variation (\%) of the net outstanding loans to the economy, first globally (cooperative versus joint-stock), and then according to type of bank. As shown in Appendix 5, (Model 1, Equation 8) a significant and negative coop 0 coefficient confirms the statistical observation in favor of joint-stock banking groups, which contradicts the theoretical as sumptions. More precisely, the significance of the MHcoop parameter (at 10\% threshold, see Appendix 5, Model 2, Equation 8) leads us to conclude that among the different types of cooperative group, only the mid-hybrid groups experienced a significant slowdown in the increase of their loans.

We also ran a model estimating the loans on assets ratio. It confirms the fact that, at the core of the cris is, and despite this evolution, all of the different types of cooperative groups significantly differ from joint-stocks: their activity is still much more credit-oriented (see Appendix 6, Equation 11).

However, it should be noticed that the available information on the banking loans is very poor: it was not possible to control the global change of rate by other variables, such as maturity, the profile of customers who obtained a credit, required collateral, interest margin, etc. Those variables may have evolved differently during the crisis and could have played a role in explaining a tightening in the credit supply, especially to SMEs.

In the final section, we analyze the behavior of the different types of banking group during the period 2009-10, to as sess their resilience.

\footnotetext{
${ }^{6}$ The estimated coefficients were significant for Canada and Spain (5\% threshold), and Portugal, Italy, and Finland (10\%). Howe ver, none of them remained significant once Dexia-France was withdrawn from the sample. 


\subsection{Resilience}

Although 2010 cannot be considered to mark the end of the crisis, the period 2009-10 was a remission phase for a lot of banks, especially plc banks, whose stock prices have once again increased on the financial market. In 2011-12, the features of the crisis were changing, with the easing of the financial crisis due to toxic assets in the banks' balance sheets, and the deepening of the economic crisis (especially in Europe, where it was reinforced by the sovereign debt crisis). For this reason we aimed to as sess the resilience of the different types of banking groups over the period 200910 only, observing the same indicators. We first compared the sample of cooperative groups to that of joint-stock groups; then, we introduced the different categories of cooperative group in our analysis. As we implemented a similar methodology (a statistical observation followed by an econometric estimation), here we focus directly on the main results.

As suggested in Appendix 2, there is no clear evidence of the greater res ilience of joint-stock groups than cooperative groups (and vice versa). The average evolution apparently depends on the indicator, the type of cooperative bank, and the country.

A first look at Appendix 2 enables us to state that joint-stock banking groups have been recovering, once again reaching in 2010 a level of $z$-score comparable to that of 2006. Despite a higher level on this ratio for the cooperative groups in 2010 than in 2006, the situation differs according to degree of hybridization, with an evolution clearly in favor of the mid-hybrid groups, which reinforced their strength over the period 2008-10.

These primarily results are confirmed by the estimated equation controlled by the country-dummies, run on the rate of change of the z-score (cf. Appendix 3, Model 1, Equation 3): a significant and negative coop $\square$ coefficient for the cooperative groups suggests greater resilience on average for joint-stock groups. It should be mentioned that, as the variation of the z-score is considered in percentage, it is not surprising that the joint-stock banks, which were most affected during the period 2006-8, also exhibit the highest rate of growth during the remission period. Nevertheless, their greater resilience on this indicator is only confirmed when compared to that of the low-hybrid cooperative groups, as only the LHcoopacoefficient is significant and negative (cf. Appendix 3, Model 2, Equation 3). Low-hybrids probably experienced the greatest difficulty in raising equity and thus in stabilizing the z-score, as the only option for them was to issue new membershares among their local members.

If we focus on financial performance (RoEa-09-10, see Appendix 4, Equation 6), the conclusions are different: neither the Coop acoefficient (cooperative versus joint-stock), nor the acoefficients according to the degree of hybridization proves to be significant. ${ }^{7}$ This result suggests that the joint-stock groups have not performed better than cooperative groups. They have not regained the comparative advantage they held prior to the financial crisis.

When we observe contributions to the financing of the economy (see Appendix 2, Dloans08-10), the situation is also contrasted: globally, the net outstanding of the loans keeps growing for all types of bank. The joint-stock banking groups do not seem to perform better on this indicator, except when compared to low-hybrid cooperative banks. Yet this result is not confirmed by the estimated model, controlling by the country-dummies (see Appendix 5, Equation 9) and the loans on assets ratio still favors cooperative groups in 2010 (see Appendix 6, Equation 12).

\section{CONCLUSION}

This research is a preliminary step toward analyzing how different features in governance and organization have played a role in explaining the (in)efficiency of cooperative banking in times of crisis. Regardless of their status (cooperative versus joint-stock), all banking groups have been affected by the crisis. However, before it began, cooperative banking groups were apparently more able to resist: they were better capitalized, their activity and their incomes were less volatile, and they made a real contribution to global financial stability. Consequently, they were expected to be better able to face the crisis. Globally, this assumption is validated by our analysis. However, their

\footnotetext{
${ }^{7}$ The financial performance of the joint-stock groups was deeply influenced by the bankruptcy of Dexia. When this bank is removed from the sample, only the Lhcoop coefficient turns out to be significant on the 2009-10 sub-period, with a negative sign. 
degree of resistance to the crisis also depends on their features. We have shown that high-hybrid groups behave no differently from joint-stock banking groups, if we consider the z-score or financial performance indicators. This was true prior to the crisis, and is also true in terms of resistance or resilience to the crisis. Consequently, among cooperative groups, high-hybrids have been most affected by the crisis.

We also pointed out that mid-hybrid cooperative groups were best able to withstand the crisis: not only was their $z$ score higher before the crisis, but it was even reinforced by the end of the period. In contrast, low-hybrid groups were weakened, especially during the second phase of the financial crisis.

Despite serious difficulties that have affected their strength (a larger decline in $z$-score), joint-stock banking groups have been able to rebound and to recover, thus demonstrating their resilience to the financial crisis. However, whereas return on equity was clearly in their favor before the crisis, they lost their comparative advantage, so that, over the whole period of the crisis (2007-11) there is no longer a significant difference (see Appendix 5, Equation 9).

Finally, there is no evidence that cooperative banking groups continued to provide more sustainable financing to the economy in times of crisis, if we consider the global variation of banking loans. Yet, at the end of the period, they still exhibited a loans on assets ratio larger than that of the joint-stock banks, which denotes activity that is still more credit-oriented. Nevertheless, this result may hide different behaviors in terms of credit supply. However, it was impossible to proceed further, due to a lack of data (maturity, collaterals, interest margins, and so on).

\section{AUTHOR BIOGRAPHY}

Mireille Jaeger is Emeritus Professor (University of Lorraine, France). She is a member of the academic research centre CEREFIGE, where she was previously Director. Her research fields include banking, cooperative banking, investment funds and venture capital. E-mail: mireille.jaeger@univ-lorraine.fr

Yasmina Lemzeri holds a Ph.D in Management Science, whose topic is directly linked with cooperative banking. She is a member of the academic research centre CEREFIGE. E-mail: yasmina.lemzeri@univ-lorraine.fr

Jean-Noel Ory is a full Profess or of Financial Management (University of Lorraine, France). He is a member of the academic research centre CEREFIGE, where he is currently in charge of the finance, control and accounting research team. He is also the head of an International Finance Master (University of Lorraine). His research fields mainly include cooperative banking and credit rating agencies. Email jean-noel.ory@univ-lorraine.fr (corresponding author)

\section{REFERENCES}

Akella, S.R. and Greenbaum, S.I. (1988). Savings and Loans Ownership Structure and Expense Preference. Journal of Banking and Finance, 12, 419-437.

Allen, F. and Gale, D. (2004). Competition and Financial Stability. Journal of Money, Credit and Banking, 36(3), 453-480.

Altman, E.I. (1968). Financial Ratios, Discriminant Analy sis and the Prediction of Corporate Bankruptcy. The Journal of Finance, September. 23(4), 589-609

Amess, K. (2002). Financial Institutions, the Theory of the Firm and Organizational Form. The Service Industries Journal, 22(2), 129-148.

Ayadi, R., Llewellyn, D., Schmidt, R., Arbak, E. and De Groen, W.P. (2010). Investing Diversity in the Banking Sector in Europe. Centre for European Policy Studies, Brussel.

Beltratti, A. and Stultz, R.M. (2011). Why Did Some Banks Perform Better during the Credit Crisis? A Cross-Country Study of the Impact of Governance and Regulation. Fisher College of Business Working Paper No. 2009-03-012.

Berger, A.N. and Mester, L.J. (1997). Inside the Black Box: What Explains Differences in the Efficiency of Financial Institutions. Journal of Banking and Finance, 21, 895-947.

Caprio, G., Laeven, L. and Levine, R. (2007). Governance and Bank Valuation. Journal of Financial Intermediation, $16,584-617$.

Chiaramonte, L., Poli F. and Oriani M.E. (2013). Are Cooperative Banks a Lever for Promoting Bank Stability? Evidence from the Recent Financial Crisis in OECD Countries. European Financial Management, 21(2), 1-33

Desrochers, M. and Fischer, K. (2005). The Powers of Networks : Integration and Financial Cooperative Performance. Annals of Public and Cooperative Economics, 76 (3), 307-354

Fonteyne, W. (2007). Cooperative Banks in Europe: Policy Issues. IMF Working Paper, WP/07/159. 
Groeneweld, J. (2011), Morality and Integrity in Cooperative Banking. Ethical Perspective, 18(4), 515-40.

Gurtner E., Jaeger, M. and Ory, J.N. (2002). Le statut de coopérative est-il source d'efficacité dans le secteur bancaire. Revue d'Economie Financière, 67, 133-163,

Gurtner, E., Jaeger, M. and Ory, J.N. (2006). La banque à forme coopérative peut elle soutenir durablement la compétition avec la banque SA ?. Finance Contrôle Stratégie , 9(2), 121-157.

Hansmann, H. (1985). The Organization of Insurance Companies: Mutual versus Stocks. Journal of Law, Economics and Organization, 1(1), 125-153.

Hansmann, H. and Kraakman, R. (2001). The End of History for Corporate Law. Harvard Discussion Paper $n^{\circ} 280$.

Hart, O. and Moore, J. (1990). Property rights and the nature of the firm. Journal of Political Economy, 98, December, 11191158.

Hesse, H. and Cihak, M. (2007). Cooperative Banks and Financial Stability. IMF Working Paper, WP/072.

Laeven, L. and Levine, R. (2008). Bank Gouvernance, Regulation, and Risk taking. NBER WP 14113.

Lamm-Tennant, J. and Starks, L.C. (1993). Stock versus Mutual Ownership Structures: the Risk Implications. The Journal of Business, 66(1), 29-46.

Ory, J.-N., Gurtner, E. and Jaeger, M. (2006), The Challenges of the Recent Changes in the French Cooperative banking Groups. RECM A, October, 43-59.

Ory J.N and Lemzeri, Y. (2012). Efficiency and Hybridization in Cooperative Banking: the French case. Annals of Public and Cooperative Economics, 83(2), 215-250.

Ory J.N, De Serres, A. and Jaeger, M. (2013). Comment résister à l'effet de normalisation: le défi des banques coopératives. la Revue des Sciences de Gestion, 258, 69-82 RASMUSEN, E. (1988). Stock Banks and Mutual Banks. Journal of Law and Economics, 31,395-422. 


\section{APPENDIX 1}

Distribution of the banking groups included in the sample, according to their status

Table 1

\begin{tabular}{|c|c|c|c|c|c|}
\hline Name & Country & $\begin{array}{c}\text { Coop: low- } \\
\text { hybrid }\end{array}$ & $\begin{array}{c}\text { Coop: } \\
\text { mid-hybrid }\end{array}$ & $\begin{array}{c}\text { Coop: } \\
\text { high-hybrid } \\
\end{array}$ & Joint-stock \\
\hline $\begin{array}{l}\text { Bank für Arbeit und Wirtschaft und Österreichische } \\
\text { Postsparkasse Aktiengesellschaft-BAWAG PSK Group } \\
\text { (consolidated) }\end{array}$ & Austria & & & & $\mathrm{X}$ \\
\hline Oesterreichische Volksbanken AG (aggregated) & Austria & $\mathrm{X}$ & & & \\
\hline Raiffeisen Group (consolidated + aggregated) & Austria & & & $\mathrm{X}$ & \\
\hline $\begin{array}{l}\text { Bank of Nova Scotia (The) - SCOTIABANK } \\
\text { (consolidated) }\end{array}$ & Canada & & & & $\mathrm{X}$ \\
\hline $\begin{array}{l}\text { Canadian Imperial Bank of Commerce CIBC } \\
\text { (consolidated) }\end{array}$ & Canada & & & & $\mathrm{X}$ \\
\hline Toronto Dominion Bank (consolidated) & Canada & & & & $\mathrm{X}$ \\
\hline Royal Bank of Canada RBC (consolidated) & Canada & & & & $\mathrm{X}$ \\
\hline Desjardin Group (consolidated) & Canada & & $\mathrm{X}$ & & \\
\hline Coast Capital Savings Credit Union (consolidated) & Canada & & $\mathrm{X}$ & & \\
\hline Vancouver City Savings Credit Union (consolidated) & Canada & & $\mathrm{X}$ & & \\
\hline Commerzbank AG (consolidated) & Germany & & & & $\mathrm{X}$ \\
\hline Deutsche Bank AG (consolidated) & Germany & & & & $\mathrm{X}$ \\
\hline Deutsche Postbank AG (consolidated) & Germany & & & & $\mathrm{X}$ \\
\hline $\begin{array}{l}\text { DZ Bank group + Volksbanken \& German Raiffeisen } \\
\text { (consolidated + aggregated) }\end{array}$ & Germany & & $\mathrm{X}$ & & \\
\hline Banco Bilbao Vizcaya Argentaria SA (consolidated) & Spain & & & & $\mathrm{X}$ \\
\hline $\begin{array}{l}\text { Banco Espanol de Crédito SA, BANESTO } \\
\text { (consolidated) }\end{array}$ & Spain & & & & $\mathrm{X}$ \\
\hline Banco Santander SA (consolidated) & Spain & & & & $\mathrm{X}$ \\
\hline Union National de Cooperativas de Crédito (aggregated) & Spain & $\mathrm{X}$ & & & \\
\hline Nordea Bank Finland Plc (consolidated) & Finland & & & & $\mathrm{X}$ \\
\hline Sampo Bank Plc (consolidated) & Finland & & & & $\mathrm{X}$ \\
\hline OP-Pohjola Group (consolidated) & Finland & & & $\mathrm{X}$ & \\
\hline BNP Paribas (consolidated) & France & & & & $\mathrm{X}$ \\
\hline Dexia-Crédit Local, France (consolidated) & France & & & & $\mathrm{X}$ \\
\hline Société Générale (consolidated) & France & & & & $\mathrm{X}$ \\
\hline
\end{tabular}

(T able 1 continued on next page) 
(Table 1 continued)

\begin{tabular}{|c|c|c|c|c|c|}
\hline Name & Country & $\begin{array}{l}\text { Coop: low- } \\
\text { hybrid }\end{array}$ & $\begin{array}{c}\text { Coop: } \\
\text { mid-hybrid }\end{array}$ & $\begin{array}{c}\text { Coop: } \\
\text { high-hybrid }\end{array}$ & Joint-stock \\
\hline Crédit Agricole Group (consolidated) & France & & & $\mathrm{X}$ & \\
\hline Crédit Coopératif Group (consolidated) & France & & $\mathrm{X}$ & & \\
\hline Credit Mutuel Group (consolidated) & France & & $\mathrm{X}$ & & \\
\hline Banques Populaires Group (consolidated) & France & & & $\mathrm{X}$ & \\
\hline Caisse d'Epargne Group (consolidated) & France & & & $\mathrm{X}$ & \\
\hline Barclays Bank Plc (consolidated) & UK & & & & $\mathrm{X}$ \\
\hline HSBC Bank plc (consolidated) & UK & & & & $\mathrm{X}$ \\
\hline Lloyds TSB Bank Plc (consolidated) & UK & & & & $\mathrm{X}$ \\
\hline Royal Bank of Scotland Plc (The) (consolidated) & UK & & & & $\mathrm{X}$ \\
\hline Co-operative Bank Plc (The) (aggregated) & UK & $\mathrm{X}$ & & & \\
\hline $\begin{array}{l}\text { Banca Monte dei Paschi di Siena SpA-Gruppo Monte } \\
\text { dei Paschi di Siena }\end{array}$ & Italy & & & & $\mathrm{X}$ \\
\hline Intesa Sanpaolo (consolidated) & Italy & & & & $\mathrm{X}$ \\
\hline UniCredit SpA (consolidated) & Italy & & & & $\mathrm{X}$ \\
\hline $\begin{array}{l}\text { Banche di Credito Cooperativo - Federcasse } \\
\text { (aggregated) }\end{array}$ & Italy & $\mathrm{X}$ & & & \\
\hline $\begin{array}{l}\text { (Assoc. Nazionale fra) le Banche Popolari } \\
\text { (consolidated) }\end{array}$ & Italy & & & $X$ & \\
\hline ING Bank NV (consolidated) & Netherlands & & & & $\mathrm{X}$ \\
\hline LeasePlan Corporation NV (consolidated) & Netherlands & & & & $\mathrm{X}$ \\
\hline NIBC Bank NV (consolidated) & Netherlands & & & & $\mathrm{X}$ \\
\hline SNS Bank N.V. (consolidated) & Netherlands & & & & $\mathrm{X}$ \\
\hline Rabobank Group (consolidated) & Netherlands & & $X$ & & \\
\hline $\begin{array}{l}\text { Banco Comercial Português, SA-Millennium bcp } \\
\text { (consolidated) }\end{array}$ & Portugal & & & & $\mathrm{X}$ \\
\hline Banco Espirito Santo SA (consolidated) & Portugal & & & & $\mathrm{X}$ \\
\hline Crédito Agricola (aggregated) & Portugal & $\mathrm{X}$ & & & \\
\hline
\end{tabular}

Key:

Joint-stock: joint-stock banking groups

Coop: cooperative banking groups

- low-hybrid: low degree of hybridization

- $\quad$ mid-hybrid: intermediate degree of hybridization

- high-hybrid: high degree of hybridization 
The Journal of Applied Business Research - September/October 2016

Volume 32, Number 5

\section{APPENDIX 2}

Resistance/resilience indicators (different types of banking group)

Table 2

\begin{tabular}{|c|c|c|c|c|c|}
\hline & LHcoop & MHcoop & HНcoop & Coop & Joint-stock \\
\hline \multicolumn{6}{|l|}{ Before the crisis } \\
\hline Z-score 2006 & 23.7 & 62.9 & 22.1 & 38.5 & 19.4 \\
\hline RoEa 2005-06 (\%) & 9.8 & 10.3 & 13.2 & 11.1 & 15.3 \\
\hline Loans/assets $2006(\%)$ & 66.2 & 69.9 & 55.6 & 64.1 & 50.3 \\
\hline \multicolumn{6}{|l|}{ Resistance indicators } \\
\hline Z-score 2008 & 21.3 & 62.1 & 15.9 & 35.8 & 15.4 \\
\hline$\Delta$ z-score $06-08(\%)$ & -6 & -5.7 & -29.4 & -9.1 & -24.6 \\
\hline RoEa 07-08 (\%) & 7.9 & 6.8 & 5.2 & 6.6 & 6.5 \\
\hline Aloans 06-08 (\%) & 12 & 5.07 & 18.6 & 11.5 & 25.7 \\
\hline Loans on assets 2008 & 67.6 & 66.3 & 52.6 & 62.1 & 50.5 \\
\hline \multicolumn{6}{|l|}{ Resilience indicators } \\
\hline Z-score 2010 & 21.3 & 72 & 20 & 40.6 & 20.3 \\
\hline$\Delta \mathrm{z}$-score $08-10(\%)$ & -3.3 & 20.2 & 34.4 & 18.4 & 47.5 \\
\hline RoEa 09-10 & 0.75 & 7.65 & 5.52 & 5.02 & 2.97 \\
\hline$\Delta$ loans $08-10(\%)$ & 0.5 & 19.4 & 7.9 & 10.3 & 10.3 \\
\hline Loans on assets 2010 & 66.2 & 68.3 & 55.4 & 63.4 & 51.7 \\
\hline \multicolumn{6}{|l|}{ Total period } \\
\hline$\Delta \mathrm{z}$-score $06-10(\%)$ & -9.8 & 12.5 & -7.6 & -0.4 & 4.3 \\
\hline$\Delta$ loans 06-10 (\%) & 12.8 & 25.5 & 27.05 & 22.5 & 36.9 \\
\hline RoEa 07-11 (\%) & 2.2 & 7.3 & 5 & 5.1 & 4.8 \\
\hline
\end{tabular}

Key:

StockB : joint-stock banking groups

CoopB : cooperative banking groups

LHcoop: low-hybrid cooperative groups

MHcoop: mid-hybrid cooperative groups

HHcoop: high-hybrid cooperative groups

$\mathrm{z}$-score $=(\mathrm{K}+\mu) / \sigma$,

where $\mathrm{K}$ is the ratio capital equity/total assets, $\mu$ is the return of the assets (RoA), and $\sigma$ is the standard deviation of the RoA

$\Delta \mathrm{z}$-score: $(\%)=\left(\left(\right.\right.$ zscore $_{\mathrm{t}}-$ zscore $\left._{\mathrm{t}-\mathrm{k}}\right) /$ zscore $\left._{\mathrm{t}-\mathrm{k}}\right) * 100$

Loans: net outstanding of banking loans to the economy, excluding interbanking lending

Assets: total of assets (end of year)

$\Delta$ loans: $(\%)=\left(\left(\right.\right.$ loans $_{\mathrm{t}}-$ loans $\left._{\mathrm{t}-\mathrm{k}}\right) /$ loanst-k $\left._{\mathrm{k}}\right) * 100$

$\mathrm{RoEa}(\%)$ : average annualized return on equity 


\section{APPENDIX 3}

The incidence of the financial crisis on the z-score indicator, according to the ownership status of the banks

\section{Table 3}

\begin{tabular}{|c|c|c|c|}
\hline & Equation1 & Equation 2 & Equation 3 \\
\hline Dependent variable & Z-score 2006 & $\Delta \_z s c o r e 2006-8$ & $\Delta \_$zscore $2008-10$ \\
\hline $\begin{array}{l}\text { Coop } \\
\text { p-value } \\
(\text { model 1) }\end{array}$ & $\begin{array}{l}22.07 \\
<0.01 * * *\end{array}$ & $\begin{array}{l}15.5 \\
0.04 * *\end{array}$ & $\begin{array}{r}-32.8 \\
0.05 * *\end{array}$ \\
\hline $\begin{array}{l}\text { LHcoop } \\
\text { p-value } \\
(\text { model } 2)\end{array}$ & $\begin{array}{l}6.48 \\
0.509\end{array}$ & $\begin{array}{l}16 \\
0.21\end{array}$ & $\begin{array}{l}-66.1 \\
\quad 0.02 * *\end{array}$ \\
\hline $\begin{array}{l}\text { МHcoop } \\
\text { p-value } \\
(\text { model } 2)\end{array}$ & $\begin{array}{l}44.52 \\
<0.0001 * * *\end{array}$ & $\begin{array}{l}21.3 \\
0.07 *\end{array}$ & $\begin{array}{r}-18.4 \\
0.45\end{array}$ \\
\hline $\begin{array}{l}\text { HHcoop } \\
\text { p-value } \\
(\text { model } 2)\end{array}$ & $\begin{array}{l}8.86 \\
0.356\end{array}$ & $\begin{array}{l}6.9 \\
0.58\end{array}$ & $\begin{array}{r}-14.6 \\
0.58\end{array}$ \\
\hline
\end{tabular}

Significance: $*(10 \%), * *(5 \%), * * *(1 \%)$

Key:

Estimated model (level):

$z$-score $=c+\alpha$ Coop $+\sum \beta_{p} D_{p}+\varepsilon($ model 1$)$

$z$-score $=c+\alpha 1$ LHcoop $+\alpha 2$ MHcoop $+\alpha 3$ HHcoop $+\sum \beta_{p} D_{p}+\varepsilon($ model 2$)$,

Estimated model (rate of change):

$\Delta z$-score $=c+\alpha \operatorname{Coop}+\sum \beta_{p} D_{p}+\varepsilon($ model 1$)$

$\Delta z$-score $=c+\alpha$ l LHcoop $+\alpha 2$ MHcoop $+\alpha 3$ HHcoop $+\sum \beta_{p} D_{p}+\varepsilon($ model 2$)$,

With:

$z$-score $=(K+\mu) / \sigma$,

where $K$ is the ratio capital equity/total assets, $\mu$ is the return of the assets (RoA), and $\sigma$ is the standard deviation of the RoA

$\Delta z-\left(\right.$ score $(\%)=\left(\left(\right.\right.$ zscore $_{t}-$ zscore $\left._{t-k}\right) /$ zscore $\left._{t-k}\right) * 100$

Coop: cooperative banking groups

LHcoop: low-hybrid cooperative groups

MHcoop: mid-hybrid cooperative groups

HHcoop: high-hybrid cooperative groups 
The Jo urnal of Applied Business Research - September/October 2016

Volume 32, Number 5

\section{APPENDIX 4}

The incidence of the financial crisis on the financial performance, according to the ownership status of the banks

Table 4

\begin{tabular}{l|c|c|c|c}
\hline & Equation 4 & Equation 5 & Equation 6 & Equation 7 \\
\hline \multicolumn{1}{c|}{ Dependent variable } & RoEa 2005-6 & RoEa 2006-8 & RoEa 2009-10 & RoEa 2007-11 \\
\hline $\begin{array}{l}\text { Coop } \\
\text { p-value } \\
\text { (model 1) }\end{array}$ & -4.08 & 3.3 & 4.2 & 2 \\
\hline $\begin{array}{l}\text { LHcoop } \\
\text { p-value } \\
\text { (model 2) }\end{array}$ & $0.004 * * *$ & 0.49 & 0.4 & 0.52 \\
\hline $\begin{array}{l}\text { MHcoop } \\
\text { p-value } \\
\text { (model 2) }\end{array}$ & -5.73 & 0.55 & -5.3 & -2.4 \\
\hline $\begin{array}{l}\text { HHcoop } \\
\text { p-value } \\
\text { (model 2) }\end{array}$ & $0.01 * * *$ & 0.94 & 0.5 & 0.6 \\
\hline
\end{tabular}

Significance: $*(10 \%), * *(5 \%), * * *(1 \%)$

Key:

Estimated model:

$R o E a_{t, t+k}=c+\alpha \operatorname{Coop}+\sum \beta_{p} D_{p}+\varepsilon($ model 1$)$

$R o E a_{t, t+k}=c+\alpha$ l LHcoop $+\alpha 2$ MHcoop $+\alpha 3$ HHcoop $+\sum \beta_{p} D_{p}+\varepsilon($ model 2$)$,

With:

RoEa: (\%): Average annualized return on equity

Coop: cooperative banking groups

LHcoop: low-hybrid cooperative groups

MHcoop: mid-hybrid cooperative groups

HHcoop: high-hybrid cooperative groups 


\section{APPENDIX 5}

The incidence of the financial crisis on outstanding loans to the economy, according to the ownership status of the banks.

Table 5

\begin{tabular}{l|c|c}
\hline & Equation 8 & Equation 9 \\
\hline \multicolumn{1}{c|}{ Dependent variable } & $\Delta$ loans06-08 & $\Delta \_$loans08_10 \\
\hline $\begin{array}{l}\text { Coop } \\
\text { p-value }\end{array}$ model 1) & -17.4 & 0.76 \\
\hline $\begin{array}{l}\text { LHcoop } \\
\text { p-value } \\
\text { (model 2) }\end{array}$ & $0.02 * *$ & 0.93 \\
\hline $\begin{array}{l}\text { MHcoop } \\
\text { p-value } \\
\text { (model 2) }\end{array}$ & -14.9 & -7.7 \\
\hline $\begin{array}{l}\text { HHcoop } \\
\text { p-value } \\
\text { (model 2) }\end{array}$ & 0.25 & 0.63 \\
Significance: $*(10 \%), * *(5 \%), * *(1 \%)$ & -21.5 & 5.9 \\
Key: & $0.07 *$ & 0.68 \\
\hline
\end{tabular}

Significance: $*(10 \%), * *(5 \%), * * *(1 \%)$

Key:

Estimated model:

$\Delta \_$loans $t_{t, t+k}=c+\alpha$ Coop $+\sum \beta_{p} D_{p}+\varepsilon($ model 1$)$

$\Delta \_$loans $s_{t, t+k}=c+\alpha$ L LHcoop $+\alpha 2$ MHcoop $+\alpha 3$ HHcoop $+\sum \beta_{p} D_{p}+\varepsilon($ model 2$)$

With:

$\Delta$ loans: (\%): rate of change of the net outstanding of loans to the economy

Coop : cooperative banking groups

LHcoop: low-hybrid cooperative groups

MHcoop: mid-hybrid cooperative groups

HHcoop: high-hybrid cooperative groups 


\section{APPENDIX 6}

Loans on assets, according to the ownership status of the banks .

\section{Table 5}

\begin{tabular}{|c|c|c|c|}
\hline & Equation10 & Equation 11 & Equation 12 \\
\hline Dependent variable & Loans on assets 2006 & Loans on assets 08 & Loans on assets 10 \\
\hline $\begin{array}{l}\text { Coop } \\
\text { p-value } \\
\text { (model 1) }\end{array}$ & $\begin{array}{l}17.8 \\
<0.01 * * *\end{array}$ & $\begin{array}{l}15.6 \\
<0.01 * * *\end{array}$ & $\begin{array}{l}14.8 \\
<0.01 * * *\end{array}$ \\
\hline $\begin{array}{l}\text { LHcoop } \\
\text { p-value } \\
\text { (model 2) }\end{array}$ & $\begin{array}{l}14.9 \\
0.05 * *\end{array}$ & $\begin{array}{l}16.3 \\
0.05 * *\end{array}$ & $\begin{array}{l}14.6 \\
0.05 * *\end{array}$ \\
\hline $\begin{array}{l}\text { MHcoop } \\
\text { p-value } \\
\text { (model } 2 \text { ) }\end{array}$ & $\begin{array}{l}23.6 \\
<0.01 * * *\end{array}$ & $\begin{array}{l}19.3 \\
<0.01 * * *\end{array}$ & $\begin{array}{l}19 \\
<0.01 * * *\end{array}$ \\
\hline $\begin{array}{l}\text { HHcoop } \\
\text { p-value } \\
\text { (model } 2)\end{array}$ & $\begin{array}{l}13.1 \\
0.07 *\end{array}$ & $\begin{array}{r}10.1 \\
0.16\end{array}$ & $\begin{array}{l}9,4 \\
0.2\end{array}$ \\
\hline
\end{tabular}

Significance: *(10\%), **(5\%), ***(1\%)

Key

Estimated model:

Loans on assets $t_{t}=c+\alpha \operatorname{Coop}+\sum \beta_{p} D_{p}+\varepsilon($ model 1$)$

Loans on assets ${ }_{t}=c+\alpha 1$ LHcoop $+\alpha 2$ MHcoop $+\alpha 3$ HHcoop $+\sum \beta_{p} D_{p}+\varepsilon($ model 2$)$

With:

Loans on assets $(\%)=$ outstanding of loans to the economy $/$ total assets

Coop : cooperative banking groups

LHcoop: low-hybrid cooperative groups

MHcoop: mid-hybrid cooperative groups

HHcoop: high-hybrid cooperative groups 
NOTES 